
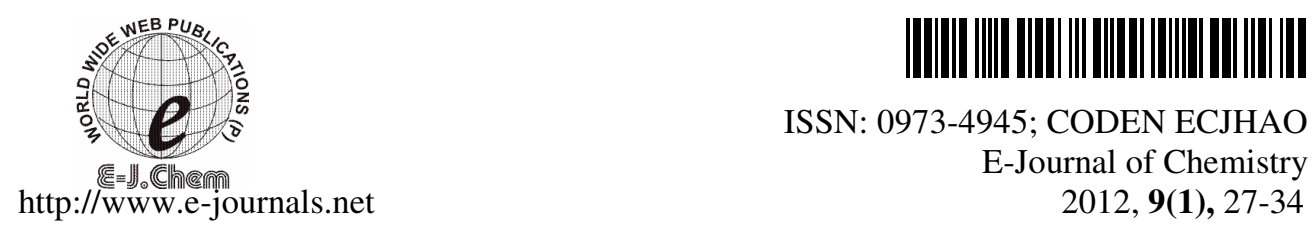

ISSN: 0973-4945; CODEN ECJHAO

E-Journal of Chemistry

2012, 9(1), 27-34

\title{
Synthesis of Two Steroids Derivatives and its Relationship with some Physicochemical Parameters
}

\author{
LAURO FIGUEROA-VALVERDE ${ }^{\S^{*}}$, FRANCISCO DÍAZ-CEDILLO \\ and ELODIA GARCIA-CERVERA ${ }^{\S}$
}

\author{
${ }^{\S}$ Lab. Farmacoquímica, Facultad de Ciencias Químico-Biológicas, \\ Universidad Autónoma de Campeche, Av. Agustín Melgar, \\ Col Buenavista C.P.24039 Campeche Cam., México.
}

Esc. Nal. de Ciencias Biológicas del Instituto Politécnico Nacional. Prol. Carpio y Plan de Ayala s/n Col. Santo Tomas, México, D.F. C.P. 11340.

lauro_1999@yahoo.com

Received 27 February 2011; Accepted 27 April 2011

\begin{abstract}
Two danazol derivatives were synthesized and characterized by spectral analyses. In order to characterize the structural and physicochemical requirements of danazol derivatives, several parameters such HOMO-LUMO gap, $\Delta \mathrm{H}_{\mathrm{f}}, \mathrm{RMS}_{\mathrm{g}}$, dipole moment $(\mu)$ and bond length were evaluated. The results showed that HOMO and $\mu$ was high in the compound $\mathbf{5}$ in comparison with the compound $\mathbf{3}$. In conclusion all these data indicate that increase in the length of chain induce greater moment dipole and increase HOMO gap in the compound 5 with respect to 3 .
\end{abstract}

Keywords: Danazol derivatives, Steroids, Physicochemical parameters, Synthesis

\section{Introduction}

Quantitative structure-activity relationship (QSAR) studies are very important in medicinal chemistry $^{1-3}$. There are reports of QSAR studies on several steroid types ${ }^{4-6}$, for example the structure-activity analysis from a series of steroids binding to globulin was made using the electro topological state index for each atom in the molecule ${ }^{7}$. Other studies reported by Bravi $^{8}$ and Tong ${ }^{9}$ showed a comparative 3D QSAR study in a series of steroids using the comparative molecular field (CoMFA) method. Additionally, there is a report of a comparative QSAR study using CoMFA, HQSAR (hologram quantitative structure-activity relationship) methods for the steroid-receptor interaction ${ }^{10}$. Other studies have developed a 
MTD model (minimal the topologic difference) to evaluate the steroid-receptor interactions ${ }^{11,12}$. In addition, there are QSAR studies which suggest a correlation between $\log \mathrm{P}$ and lipophilicity degree for some steroids ${ }^{13}$ for example, the reports of Li et al. ${ }^{14}$ which showed that $\log \mathrm{P}$ have a correlation with the passive diffusion from some steroids. Additionally, several studies ${ }^{15,16}$ have determined the relationship of some steroid derivatives with the physicochemical descriptors such as $\log P \pi, R_{m}, V_{m}$ and the frontier molecular orbitals (HOMO-LUMO gap) ${ }^{17,18}$. All these works show several protocols for QSAR study of steroids that involved; geometry optimization, conformational analysis and electronic energy. In this work our initial design included the synthesis of two danazol derivatives and its relationship with HOMO-LUMO gap, $\Delta \mathrm{H}_{\mathrm{f}}$, $\mathrm{RMS}_{\mathrm{g}}$, dipole moment and bond length.

\section{Experimental}

General methods

Danazol succinate (1) was prepared according to a previously reported method by several investigators ${ }^{19}$. The other compounds evaluated in this study were purchased from Sigma-Aldrich Co., Ltd. The melting points for the different compounds were determined on an Electrothermal (900 model). Infrared spectra (IR) were recorded using KBr pellets on a Perkin Elmer Lambda 40 spectrometer. ${ }^{1} \mathrm{H}$ and ${ }^{13} \mathrm{C}$ NMR spectra were recorded on a Varian VXR-300/5 FT NMR spectrometer at 300 and $75.4 \mathrm{MHz}$ in $\mathrm{CDCl}_{3}$ using TMS as internal standard. EIMS spectra were obtained with a Finnigan Trace GCPolaris Q. spectrometer. Elementary analysis data were acquired from a Perkin Elmer Ser. II CHNS/0 2400 elemental analyzer.

$N$-(-Amino-ethyl)succinamic acid 1-ethynyl-10a,12a-dimethyl-2,3,3a,3b,4,5,5a,6,6a,9a,10 10a,10b,11,12,12a-hexadecahydro-1H-7-oxa-8-aza-dicyclopenta[a,h]phenanthren-1-yl ester (3).

Method A

A solution of $\mathbf{1}(100 \mathrm{mg}, 0.23 \mathrm{mmol})$, ethylenediamine $(28 \mu \mathrm{L}, 0.46 \mathrm{mmol})$ and $26 \mathrm{mg}$ boric acid $(0.42 \mathrm{mmol})$ in toluene $(10 \mathrm{~mL})$ was heated under reflux for $8 \mathrm{~h}$. The reaction was allowed to cool to room temperature and the toluene was evaporated under vacuum. The reaction mixture was dissolved in ethyl acetate $(10 \mathrm{~mL})$ and water $(20 \mathrm{~mL})$; the organic layer was separated and the aqueous layer was re-extracted with ethyl acetate $(10 \mathrm{~mL})$. The combined organic layers were washed with water $(15 \mathrm{~mL})$ and then dried over sodium carbonate (anhydrous). The organic phase was evaporated to dryness under reduced pressure (Scheme 1). The residue was purified by crystallization from methanol:water (3:1) yielding 45 $\%$ of product , m.p. $190{ }^{\circ} \mathrm{C}$; IR $v_{\max } 3380,2138,1730 \mathrm{~cm}^{-1} ;{ }^{1} \mathrm{H}$ NMR $\left(300 \mathrm{MHz}, \mathrm{CDCl}_{3}\right) \delta_{\mathrm{H}}$ : $0.96(\mathrm{~s}, 3 \mathrm{H}),, 0.98(\mathrm{~m}, 1 \mathrm{H}), 1.01(\mathrm{~s}, 3 \mathrm{H}), 1.04-1.42(\mathrm{~m}, 2 \mathrm{H}), 1.56-1.90(\mathrm{~m}, 10 \mathrm{H}), 2.10-2.26$ $(\mathrm{m}, 2 \mathrm{H}), 2.34-2.42(\mathrm{~m}, 2 \mathrm{H}), 2.49(\mathrm{t}, 2 \mathrm{H}, \mathrm{J}=6.5 \mathrm{~Hz}), 2.69(\mathrm{t}, 2 \mathrm{H}, \mathrm{J}=6.5 \mathrm{~Hz}), 2.90(\mathrm{~s}, 1 \mathrm{H})$, $2.96(\mathrm{t}, 2 \mathrm{H}), 3.30(\mathrm{t}, 2 \mathrm{H}), 4.78($ broad $), 6.53(\mathrm{~s}, 1 \mathrm{H}), 7.98(\mathrm{~s}, 1 \mathrm{H}) \mathrm{ppm} .{ }^{13} \mathrm{C} \mathrm{NMR}(74.5 \mathrm{MHz}$, DMSO- $\left.d_{6}\right) \delta_{\mathrm{C}}: 14.91(\mathbf{C}-22), 19.66(\mathbf{C}-21), 21.05(\mathbf{C}-19), 23.88(\mathbf{C}-13), 30.43,(\mathbf{C}-29), 30.60$ (C-17), 31.30 (C-28), 31.70 (C-20), $32.90 \quad$ (C-18), 33.71 (C-5), 33.84 (C-12), 37.65 (C-8), 38.70 (C-6), 39.44 (C-33), 4050 (C-34), 46.43 (C-10), 52.90 (C-9), 53.12 (C-7), 75.43 (C-27), 84.43 (C-11), 84.64 (C-26), 110.50 (C-15), 121.63 (C-4), 141.60 (C-16), 149.60 (C-3), 156.07

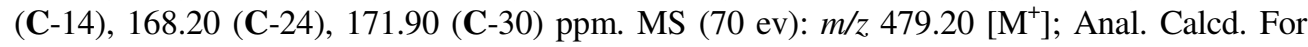
$\mathrm{C}_{28} \mathrm{H}_{37} \mathrm{~N}_{3} \mathrm{O}_{4}$ : C, 70.12; H, 7.78; N, 8.76; 0, 13.34. Found: C, 70.10; H, 7.72.

\section{Method B}

A solution of $\mathbf{1}(100 \mathrm{mg}, 0.23 \mathrm{mmol})$, ethylenediamine $(28 \mu \mathrm{L}, 0.46 \mathrm{mmol})$ and 1-ethyl-3-(3dimethylaminopropyl)carbodiimide hydrochloride $(60 \mathrm{mg}, 0.31 \mathrm{mmol})$ in acetonitrile-water 
$(10 \mathrm{~mL}, 4: 1)$. After stirring at room temperature for $18 \mathrm{~h}$, the solution was concentrated and the product was extracted with ethyl acetate and water (2:1) to give the compound $3(68 \%$ yield). Similar ${ }^{1} \mathrm{H}$ NMR and ${ }^{13} \mathrm{C}$ NMR data were obtained compared with method A product.

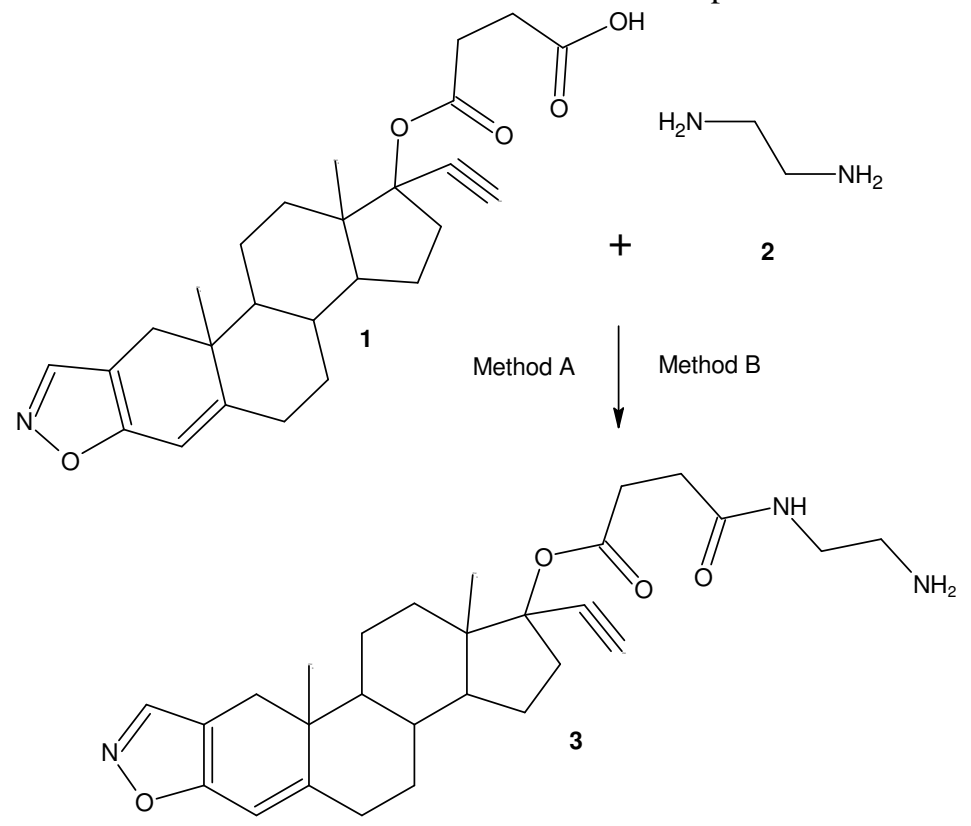

Scheme 1. Reaction of danazol succinate (1) with ethylenediamine (2) to form steroid derivative (3); Catalysts- Method A: Boric acid, Method B- 1-ethyl-3-(3-dimethyl aminopropyl)carbodiimidehydrochloride.

$\mathrm{N}$-[2-(4-Hydroxy-benzoilamino)ethyl]-succinamic acid 1-ethynyl-10a-12a-dimethyl2,3,3a,3b,4,5,5a,6,6a,9a,10,10a,10b,11,12,12a-hexadecahydro-1H-7-oxa-8-azadicyclo-penta[a,h]phenanthren-1-yl ester (5)

A solution of 3 (100 mg, 0.21 mmol), 4-hydroxybenzoic acid (40 mg, $0.29 \mathrm{mmol})$ and 1-ethyl-3-(3-dimethylaminopropyl)carbodiimide hydrochloride $(60 \mathrm{mg}, 0.31 \mathrm{mmol})$ in acetonitrile-water $(10 \mathrm{~mL}, 4: 1)$. After stirring at room temperature for $18 \mathrm{~h}$, the solution was concentrated and the product was extracted with ethyl acetate and water $(2: 1)$ to give the compound 5 (Scheme 2) with $68 \%$ yield. IR $v_{\max }, \mathrm{cm}^{-1}: 2138,1730,1650 ;{ }^{1} \mathrm{H}$ NMR (300 HMz, DMSO- $\left.d_{6}\right) \delta_{\mathrm{H}}: 0.98(\mathrm{~s}, 3 \mathrm{H}), 0.99(\mathrm{~m}, 1 \mathrm{H}), 1.01(\mathrm{~s}, 3 \mathrm{H}), 1.05-1.44(\mathrm{~m}, 2 \mathrm{H}), 1.53-1.92$ $(\mathrm{m}, 10 \mathrm{H}), 2.10-2.26(\mathrm{~m}, 2 \mathrm{H}), 2.34-2.42(\mathrm{~m}, 2 \mathrm{H}), 2.49(\mathrm{t}, 2 \mathrm{H}, \mathrm{J}=6.5 \mathrm{~Hz}), 2.69(\mathrm{t}, 2 \mathrm{H}, \mathrm{J}=6.5$ $\mathrm{Hz}), 2.90(\mathrm{~s}, 1 \mathrm{H}), 342(\mathrm{t}, 2 \mathrm{H}, \mathrm{J}=6.5 \mathrm{~Hz}), 350(\mathrm{t}, 2 \mathrm{H}, \mathrm{J}=6.5 \mathrm{~Hz}), 6.44(\mathrm{broad}, 3 \mathrm{H}), 6.53(\mathrm{~s}$, $1 \mathrm{H}), 6.95(\mathrm{~d}, 2 \mathrm{H}), 7.59(\mathrm{~d}, 2 \mathrm{H}), 7.98(\mathrm{~s}, 1 \mathrm{H}) \mathrm{ppm} .{ }^{13} \mathrm{C}$ NMR $\left(74.5 \mathrm{MHz}\right.$, DMSO- $\left.d_{6}\right) \delta_{\mathrm{C}}$ : 14.91 (C-22), 19.66 (C-21), 21.05 (C-19), 23.88 (C-13), 30.43, (C-29), 30.69 (C-17), 31.35 (C-28), 31.70 (C-20), 32.90(C-18), 33.71 (C-5), 33.84 (C-12), 37.65 (C-8), 38.71 (C-34), 39.44 (C-33), 4050 (C-6), 46.43 (C-10), 52.90 (C-9), 53.12 (C-7), 75.43 (C-27), 84.43 (C11), 84.64 (C-26), 110.50 (C-15), 115.10 (C-40, C-42), 121.63 (C-4), 127.56 (C-38), 128.92 (C-39, C-43), 141.60 (C-16), 149.60 (C-3), 156.07 (C-14), 160.42 (C-41), 162.35

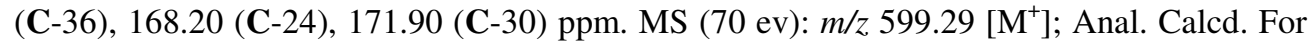
$\mathrm{C}_{35} \mathrm{H}_{41} \mathrm{~N}_{3} \mathrm{O}_{6}$ : C, 70.10; H, 6.89; N, 7.01; 0, 16.01. Found: C, 70.08; H, 6.86. 
<smiles>C#CC1(OC(=O)CCC(=O)NCCN)CCC2C3CCC4=Cc5oncc5CC4(C)C3CCC21C</smiles><smiles>C#CC1(OC(=O)CCC(=O)NCCNC(=O)c2ccc(O)cc2)CCC2C3CCC4=Cc5oncc5CC4(C)C3CCC21C</smiles>

Scheme 2. Synthesis of danazol derivative (5); reaction between the compound 3 with 4Hydroxybenzoic acid (4) using as catalyst1-ethyl-3-(3-dimethyl aminopropyl)carbodiimide hydrochloride (EDC) to form $\mathbf{5}$.

\section{Results and Discussion}

\section{Chemistry analyses}

In this study we report a straight forward route for the synthesis of two danazol derivatives. The first step was achieved by reacting 1 with ethylendiamine hydrochloride (2) to form $\mathbf{3}$ (Scheme 1) since the nature of functional groups contained in the chemical structure of this compound involves both amine and amide groups in the arm bound to steroid nucleus of $\mathbf{3}$. It is important to mention that many procedures for the formation of amide groups are known in the literature ${ }^{20-22}$, the most widely practiced method employs carboxylic acid chlorides as the electrophiles which react with the amino group in the presence of an acid scavenger ${ }^{23}$. Despite its wide scope, the former protocol suffers from several drawbacks; most notable are the limited stability of many acid chlorides and the need for hazardous reagents for their preparation (thionyl chloride) ${ }^{24}$. In this study, two different methods for amide formation were employed; in the first one the technique reported by Pingwah ${ }^{25}$ for boric acid catalyzed amidation of carboxylic acids and amines (method A) was used; in the second one we used a derivative of carbodiimide (method B) as catalyzer ${ }^{26}$ to form the compound 3. It was found that the use of carbodiimide results in higher yields compared to the amide bond formed with method A. ${ }^{1} \mathrm{H}$ NMR spectra of $\mathbf{3}$ showed chemical shifts at 0.96 and $1.01 \mathrm{ppm}$ for methyls present in the steroid nucleus. In addition, other signals at 0.98 , 1.04-2.42 ppm for hydrogens involved in the steroid nucleus were found. Other signals at 2.49-3.30 ppm for methylenes involved in the arm bound to danazol fragment were display. Finally, two signals at $2.88 \mathrm{ppm}$ for proton involved in the alkyne group and at $4.70 \mathrm{ppm}$ for hydrogens corresponding to amino groups were found. The ${ }^{13} \mathrm{C}$ NMR spectra display chemical shifts at 14.91 and $19.66 \mathrm{ppm}$ for the carbons of methyls presents in the steroid nucleus of 3. Another chemical shifts at 21.05-23.88, 30.60; 31.70-38.70, 47.43-53.12 and 110.50-156.07 ppm for carbons of methylenes involved in the steroid nucleus were exhibited. Additionally, several signals at 30.43, 31.30, 39.44 and $40.50 \mathrm{ppm}$ for carbons 
corresponding to methylenes involved in the arm bound to danazol nucleus were found. Finally, other signals at 75.43 and 84.62 for carbons involved in the alkyne group; at 168.20 ppm for ester group; at $171.90 \mathrm{ppm}$ for amide group and at 221.00 for ketone group were exhibited. The presence of $\mathbf{3}$ was further confirmed from mass spectrum which showed a molecular ion at $m / z 479.20$.

On the other hand, the second stage was achieved by reacting 3 with benzoic acid (4) in presence of 1-ethyl-3(3-dimethylamino-propyl)-carbodiimide to form 5 (Scheme 2). The results indicate that ${ }^{1} \mathrm{H}$ NMR spectrum of 5 showed signals at 0.98 and $1.01 \mathrm{ppm}$ for methyls present in the steroid nucleus. Additionally, other signals at $0.99,1.05-2.42 \mathrm{ppm}$ for hydrogens involved in the steroid nucleus were found. Other signals at $2.49-3.50 \mathrm{ppm}$ for methylenes involved in the spacer arm between danazol fragment and phenyl group were display. Finally, several signals at $6.44 \mathrm{ppm}$ for both amine and hydroxyl groups; at 6.957.59 for phenyl group were found. The ${ }^{13} \mathrm{C}$ NMR spectra display chemical shifts at 14.91 and $19.66 \mathrm{ppm}$ for the carbons of methyls presents in the steroid nucleus of $\mathbf{5}$. Other chemical shifts at 21.05-23.88, 30.69, 31.70-37-65, 40.50-53.12, 84.43, 110.50, 121.63, 141.60-156.07 ppm for carbons of methylenes involved steroid nucleus were exhibited. Additionally, several signals at 30.43-39.44 ppm for carbons corresponding to spacer arm between steroid nucleus and phenyl group were found. Finally, other signals at 115.10160.42 ppm for phenyl group; at 162.35 and $171.90 \mathrm{ppm}$ for amide groups and at 168.20 ppm for ketone group were exhibited. The presence of $\mathbf{5}$ was further confirmed from mass spectrum which showed a molecular ion at $\mathrm{m} / \mathrm{z} 599.29$.

\section{Electronic parameters}

Molecular orbital and their properties, like energy and their frontier electron density are used for predicting the most reactive position in $\pi$-electron systems and several types of reactions in conjugated system. This theory indicate that the highest occupied molecular orbital (HOMO) and lowest unoccupied molecular orbital (LUMO) values and their energy gap reflect the chemical activity of the molecule. There are reports which show that the energy gap between HOMO and LUMO have correlation with biological activity ${ }^{27}$. To evaluate these physiochemical parameters, some methods have been developed within the mathematical framework of the molecular orbital theory to evaluate the electronic properties of several compounds. For example, there are studies which showed the evaluation of the frontier molecular orbitals (HOMO-LUMO gap) of some steroids using the MINDO and ZINDO models ${ }^{28,29}$.

Analyzing these data in this study, HOMO-LUMO gap of compound 5 were evaluated using a theoretical method (ZINDO/S, hyperchem 6.0). The results showed two energy levels for HOMO $(-598.6163 \mathrm{eV})$ and for LUMO $(-0.8229007 \mathrm{eV})$ in the compound 5 (Table 1). These frontier orbital molecular values were compared with the data obtained for the compound $\mathbf{3}$, in order to evaluate if changes in the structure $\mathbf{5}$ chemical affect the energy levels. The results showed that the HOMO-LUMO gap values were different for $\mathbf{5}$ in comparison with $\mathbf{3}$. This phenomenon could be conditioned by $\pi$ orbital which is localized in the amide group involved in the spacer arm between steroid nucleus and phenyl group of $\mathbf{5}$ in comparison with $\mathbf{3}$. In addition, also the compound $\mathbf{5}$ showed other differences with respect to $\mathbf{3}$, in this case the $\pi$ orbitals are localized in the phenyl group involved in the chemical structure of $\mathbf{5}$. All these data suggest that functional groups could induce changes in the organic superconductivity of $\mathbf{5}$ as it happens in other steroid derivatives, which show that molecular orbitals $(\mathrm{C}-2 \mathrm{p})$ are aligned along of the molecular axes ${ }^{30}$, this phenomenon, could bring like consequence variations in the electronic transmittance. 
Table 1. Parameters Physicochemical (HOMO and LUMO), $\Delta \mathrm{H}_{\mathrm{f}}, \mathrm{RMS}_{\mathrm{g}}$ (RM gradient) and Dipolar Moment $(\mu)$ of compounds 3 and $\mathbf{5}$.

\begin{tabular}{cccllll}
\hline Compound & HOMO, & LUMO, & $\Delta \mathrm{H}_{\mathrm{f}} \mathrm{RMS}_{\mathrm{g}}$ & \multicolumn{2}{c}{$\mu$} \\
\cline { 5 - 7 } & $\mathrm{eV}$ & $\mathrm{eV}$ & $\mathrm{kcal} / \mathrm{mol}$ & $\mathrm{kcal} / \AA \mathrm{A}$ mol $)$ & Debyes \\
\hline 3 & -528.4316 & -1.532452 & -182113.2 & 912.1 & 4.101 \\
5 & -598.6163 & -0.8629007 & -242058.1 & 1178 & 4.460 \\
\hline
\end{tabular}

Table 2. Bond length of atoms involved in the chemical structure of compound 3

\begin{tabular}{lrllll}
\hline \multicolumn{1}{c}{ Atom } & Length & \multicolumn{1}{c}{ Atom } & Length & \multicolumn{1}{c}{ Atom } & Length \\
\hline O-C (Isoxazole ring) & 0.40694 & $\mathrm{C}_{7}-\mathrm{C}_{19}$ & 0.23121 & $\mathrm{C}_{30}-\mathrm{N}$ & 0.23001 \\
O-N (Isoxazole ring) & 0.23121 & $\mathrm{C}_{19}-\mathrm{C}_{20}$ & 0.23401 & $\mathrm{~N}-\mathrm{C}_{33}$ & 0.23001 \\
$\mathrm{~N}-\mathrm{C}_{3}$ & 0.23402 & $\mathrm{C}_{20}-\mathrm{C}_{10}$ & 0.23401 & $\mathrm{C}_{33}-\mathrm{C}_{34}$ & 0.22600 \\
$\mathrm{C}_{3}-\mathrm{C}_{4}$ & 0.23402 & $\mathrm{C}_{9}-\mathrm{C}_{10}$ & 0.23121 & $\mathrm{C}_{34}-\mathrm{N}$ & 0.23001 \\
$\mathrm{C}_{4}-\mathrm{C}_{5}$ & 0.23402 & $\mathrm{C}_{10}-\mathrm{C}_{11}$ & 0.23401 & & \\
$\mathrm{C}_{4}-\mathrm{C}_{14}$ & 0.23121 & $\mathrm{C}_{9}-\mathrm{C}_{13}$ & 0.40231 & & \\
$\mathrm{C}_{14}-\mathrm{C}_{15}$ & 0.23001 & $\mathrm{C}_{13}-\mathrm{C}_{12}$ & 0.23121 & & \\
$\mathrm{C}_{15}-\mathrm{C}_{16}$ & 0.23402 & $\mathrm{C}_{11}-\mathrm{C}_{12}$ & 0.23001 & & \\
$\mathrm{C}_{6}-\mathrm{C}_{16}$ & 0.23121 & $\mathrm{C}_{11}-\mathrm{C}_{26}$ & 0.23121 & & \\
$\mathrm{C}_{6}-\mathrm{C}_{7}$ & 0.23402 & $\mathrm{C}_{26}-\mathrm{C}_{27}$ & 0.23121 & & \\
$\mathrm{C}_{6}-\mathrm{C}_{21}$ & 0.23121 & $\mathrm{C}_{11}-\mathrm{O}($ ring $\mathrm{D})$ & 0.23121 & & \\
$\mathrm{C}_{7}-\mathrm{C}_{8}$ & 0.23001 & $\mathrm{O}_{-}-\mathrm{C}_{24}$ & 0.23121 & & \\
$\mathrm{C}_{16}-\mathrm{C}_{17}$ & 0.23001 & $\mathrm{C}_{24}=\mathrm{O}$ & 0.23402 & & \\
$\mathrm{C}_{17}-\mathrm{C}_{18}$ & 0.23402 & $\mathrm{C}_{24}-\mathrm{C}_{28}$ & 0.23402 & & \\
$\mathrm{C}_{18}-\mathrm{C}_{8}$ & 0.23121 & $\mathrm{C}_{28}-\mathrm{C}_{29}$ & 0.23121 & & \\
$\mathrm{C}_{8}-\mathrm{C}_{9}$ & 0.23402 & $\mathrm{C}_{29}-\mathrm{C}_{30}$ & 0.23001 & & \\
& & $\mathrm{C}_{30}=\mathrm{O}$ & 0.23001 & & \\
\hline
\end{tabular}

Table 3. Bond length of atoms involved in the chemical structure of compound 5

\begin{tabular}{llllll}
\hline \multicolumn{1}{c}{ Atom } & Length & Atom & Length & Atom & Length \\
\hline O-C (Isoxazole ring) & 0.40694 & $\mathrm{C}_{7}-\mathrm{C}_{19}$ & 0.23121 & $\mathrm{~N}-\mathrm{C}_{33}$ & 0.23001 \\
O-N (Isoxazole ring) & 0.23121 & $\mathrm{C}_{19}-\mathrm{C}_{20}$ & 0.23401 & $\mathrm{C}_{33}-\mathrm{C}_{34}$ & 0.23001 \\
$\mathrm{~N}-\mathrm{C}_{3}$ & 0.23402 & $\mathrm{C}_{20}-\mathrm{C}_{10}$ & 0.23401 & $\mathrm{C}_{34}-\mathrm{N}$ & 0.22600 \\
$\mathrm{C}_{3}-\mathrm{C}_{4}$ & 0.23402 & $\mathrm{C}_{9}-\mathrm{C}_{10}$ & 0.23121 & $\mathrm{~N}-\mathrm{C}_{36}$ & 0.23001 \\
$\mathrm{C}_{4}-\mathrm{C}_{5}$ & 0.23402 & $\mathrm{C}_{10}-\mathrm{C}_{11}$ & 0.23401 & $\mathrm{C}_{36}=\mathrm{O}$ & 0.23121 \\
$\mathrm{C}_{4}-\mathrm{C}_{14}$ & 0.23121 & $\mathrm{C}_{9}-\mathrm{C}_{13}$ & 0.40231 & $\mathrm{C}_{36}-\mathrm{C}_{38}$ & 0.23402 \\
$\mathrm{C}_{14}-\mathrm{C}_{15}$ (C=C) & 0.23001 & $\mathrm{C}_{13}-\mathrm{C}_{12}$ & 0.23121 & $\mathrm{C}_{38}-\mathrm{C}_{39}$ & 0.23121 \\
$\mathrm{C}_{15}-\mathrm{C}_{16}$ & 0.23402 & $\mathrm{C}_{11}-\mathrm{C}_{12}$ & 0.23001 & $\mathrm{C}_{39}-\mathrm{C}_{40}$ & 0.23001 \\
$\mathrm{C}_{6}-\mathrm{C}_{16}$ & 0.23121 & $\mathrm{C}_{11}-\mathrm{C}_{26}$ & 0.23121 & $\mathrm{C}_{40}-\mathrm{C}_{41}$ & 0.23001 \\
$\mathrm{C}_{6}-\mathrm{C}_{7}$ & 0.23402 & $\mathrm{C}_{26}-\mathrm{C}_{27}$ & 0.23121 & $\mathrm{C}_{41}-\mathrm{C}_{42}$ & 0.23001 \\
$\mathrm{C}_{6}-\mathrm{C}_{21}$ & 0.23121 & $\mathrm{C}_{11}-\mathrm{O}$ (ring $\left.\mathrm{D}\right)$ & 0.23121 & $\mathrm{C}_{42}-\mathrm{C}_{43}$ & 0.23001 \\
$\mathrm{C}_{7}-\mathrm{C}_{8}$ & 0.23001 & $\mathrm{O}_{-}-\mathrm{C}_{24}$ & 0.23121 & $\mathrm{C}_{38}-\mathrm{C}_{43}$ & 0.23001 \\
$\mathrm{C}_{16}-\mathrm{C}_{17}$ & 0.23001 & $\mathrm{C}_{24}=\mathrm{O}$ & 0.23402 & $\mathrm{C}_{41}-\mathrm{O}$ & 0.23121 \\
$\mathrm{C}_{17}-\mathrm{C}_{18}$ & 0.23402 & $\mathrm{C}_{24}-\mathrm{C}_{28}$ & 0.23402 & & \\
$\mathrm{C}_{18}-\mathrm{C}_{8}$ & 0.23121 & $\mathrm{C}_{28}-\mathrm{C}_{29}$ & 0.23121 & & \\
$\mathrm{C}_{8}-\mathrm{C}_{9}$ & 0.23402 & $\mathrm{C}_{29}-\mathrm{C}_{30}$ & 0.23001 & & \\
& & $\mathrm{C}_{30}=\mathrm{O}$ & 0.23001 & & \\
\hline
\end{tabular}


On the other hand, it is important to mention that there are studies ${ }^{31}$ which indicate that the size of the energy gap between the highest occupied and lowest unoccupied molecular orbitals (HOMO-LUMO gap) is directly related to the extent of bond-length alternation of some compounds. Therefore, in this study was interesting to evaluate the bond length of each atom involved in the chemical structure of $\mathbf{5}$ and compare it with the obtained values for the compound 3. The results indicate (c.f. Table 2 and 3) that both phenyl and amide groups involved in the structure chemical of 5 caninduce diminish the levels of energy from HOMO-LUMO gap of this compound in comparison with obtained values 3 . It is important to mention that also length of chain has been relationship with the changes in the dipole moment $(\mu)$ of $\mathbf{5}$ as it happens in other compounds ${ }^{32}$; therefore, in this study $\mu$ of $\mathbf{5}$ was evaluated and compared with the values of $\mathbf{3}$. The results showed that $\mu$ was high in $\mathbf{5}$ in comparison with 3 (c.f. Table 1); this data indicate that increase in the length of chain induce greater moment dipole.

\section{Conclusion}

In conclusion all these data indicate a relationship of physicochemical parameters HOMOLUMO gap with length of chain and $\mu$ of the compound $\mathbf{5}$.

\section{References}

1. Lee Y, Doddareddy R, Cho S, Choo H, Koh Y, Kang H and No T, J Mol Model., 2007, 13, 543-558.

2. Netzeva T I, Dearden J C, Edwards R, Worgan A D and Cronin M T, Bull Environ Contam Toxicol., 2004, 73(2), 385-391.

3. Ramos E, Vaes W, Verhaar H and Hermens J, Sci Pollut Res., 1997, 4(2), 83-90.

4. $\quad$ Sippl W, J Comput Aided Mol Des., 2000, 14(6), 559-572.

5. Tuppurainen K, Viisas M, Peräkylä M and Laatikainen R, J Comput Aided Mol Des., 2004, 18(3), 175-87.

6. Coats A, Perspect Drug Discov Design., 1998, 12, 199-203.

7. De Gregorio C, Lemont B and Hall H, J Comput Aided Mol Design, 1998, 12(6), 557-561.

8. Bravia G, Gancia E, Mascagni P, Pegna M, Todeschini R and Zaliani A, J Comput Aided Mol Design., 1997, 11(1), 79-92.

9. Tong W and Perkins R, Endocrinol., 1997, 138(9), 4022-4025.

10. Waller L, J Chem Inf Comput Sci., 2004, 44(2), 758-765.

11. Simon Z and Bohl M, Quant Struct Act Relat., 1992, 11(1), 23-28.

12. Oprea T, Ciubotariu D, Sulea T and Simon Z, Quant Struct Act Relat., 1993, 12(1), 21-26.

13. Alvarez N and Yalkowsky S, J Pharm Sci., 1997, 86(10), 1187-1189.

14. Li Y, Wang Y, Yang L, Zhang S and Liu C, Int Elect J Mol Design., 2006, 5, 60-78.

15. Figueroa-Valverde L, Díaz-Cedillo F, Camacho-Luis A, López-Ramos M and GarciaCervera E, Monatsh Chem., 2010, 141, 373-380.

16. Figueroa-Valverde L, Díaz-Cedillo F, Camacho-Luis A, López-Ramos M and GarciaCervera E, Int J Chem Tech Res., 2010, 2(3), 1553-1559.

17. Kubli-Garfias C, Mendieta J and Ricardo Vazquez, J Mol Structure (Theochem.), 1996, 388, 35-41.

18. Duddeck H, Rosenbaum D, Hani M, Elgamal A and Fayez M, Magn Reson Chem., 1986, 24, 999-1003.

19. Figueroa-Valverde L, Diaz-Cedillo F and Ceballos-Reyes G, Acta Biochem Argentin. 2010, 44(1), 37-45. 
20. Rannard S and Davis N, Org Lett., 2000, 2, 2117-2120.

21. Bode J and Sohn S, J Am Chem Soc., 2007, 129, 13798-13799.

22. Hauser R and Hoffenberg D, J Org Chem., 1955, 20, 1448-1453.

23. Medvedeva A, Andreev M,Safronova L and Sarapulova G, Arkivoc, 2001, ix, 143-149.

24. Levin D, Org Process Res Dev., 1997, 1, 182-182.20.

25. Pingwah T, Organic Syntheses, 2005, 81, 262-267.

26. DeSilva N, Am J Respir Cell Mol Biol., 2003, 29, 757-770.

27. Prasad Y, Kumar P, Smiles D and Babub P, Arkivok, 2008, xi, 266-276

28. Srivastava H, Pasha F and Singh P, Int J Quant Chem., 2005, 103(3), 237-245.

29. Ferro N, Tacoronte J, Reinard T, Bultinck P and Montero L, J Mol Structure, 2006, 758(2), 263-274

30. Cvitas T, Kovac B, Pasa-Tolic L, Rusic B and Klasinc L, Pure Appl Chem., 1989, 61(12), 2139-2150.

31. Ho C andKertesz M, J Chem Phys., 1997, 107(17), 6712-6721.

32. Pulay P, Fogarasi G, Pang F and Boggs J, J Am Chem Soc., 1979, 101(10), 2550-2560. 


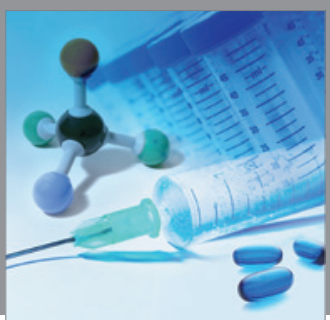

International Journal of

Medicinal Chemistry

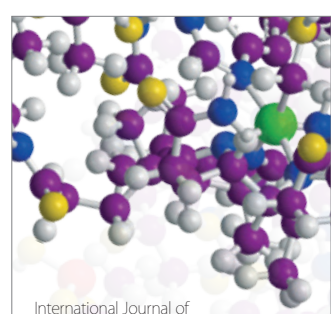

Carbohydrate Chemistry

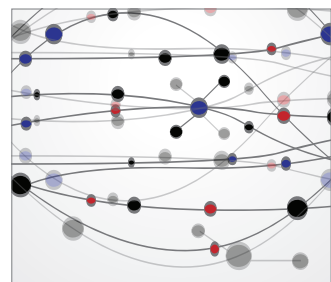

The Scientific World Journal
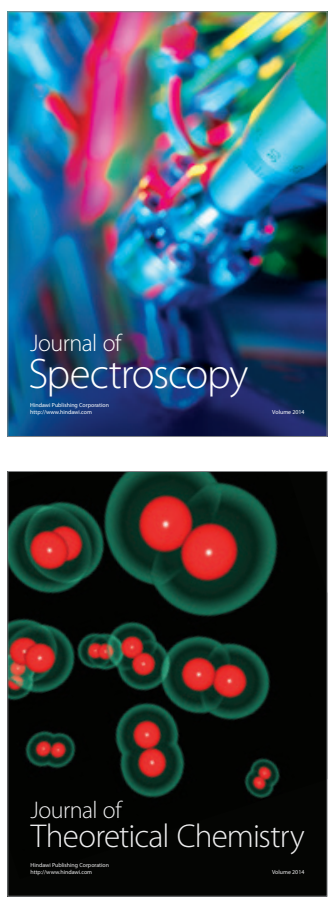
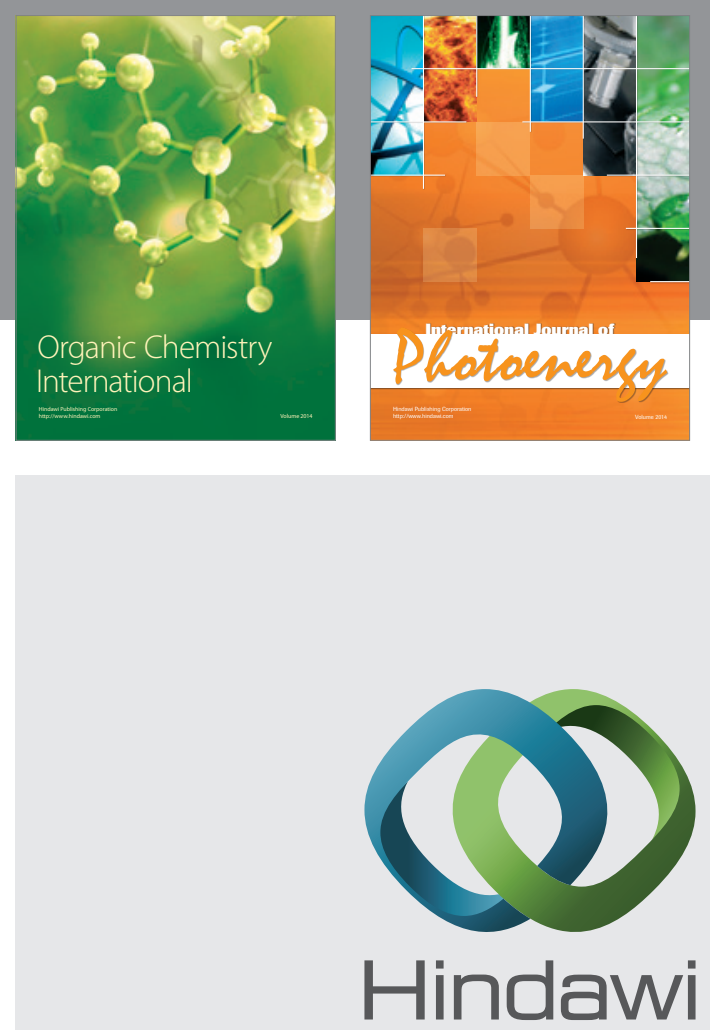

Submit your manuscripts at

http://www.hindawi.com
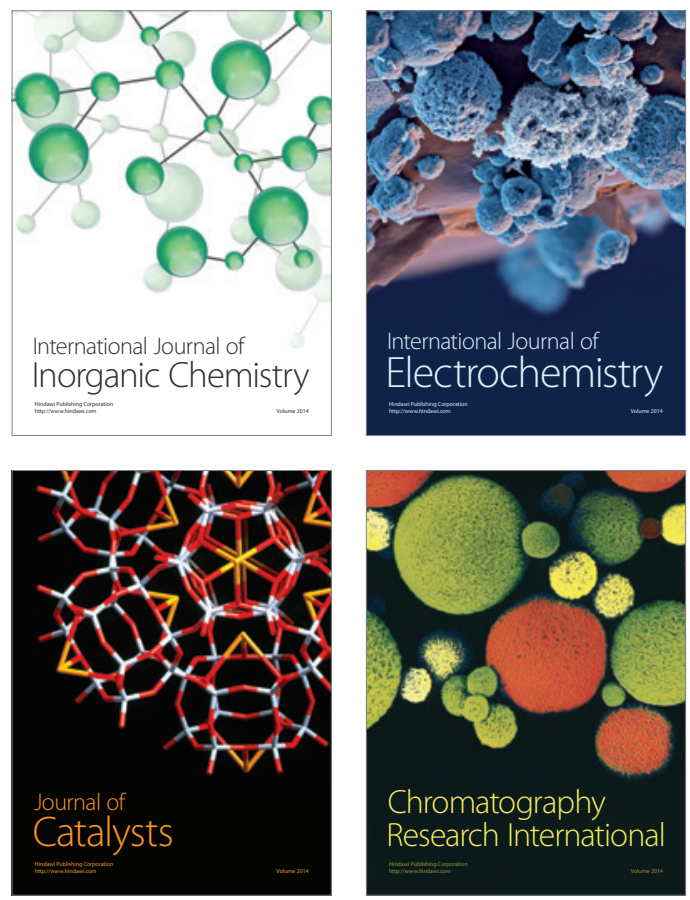
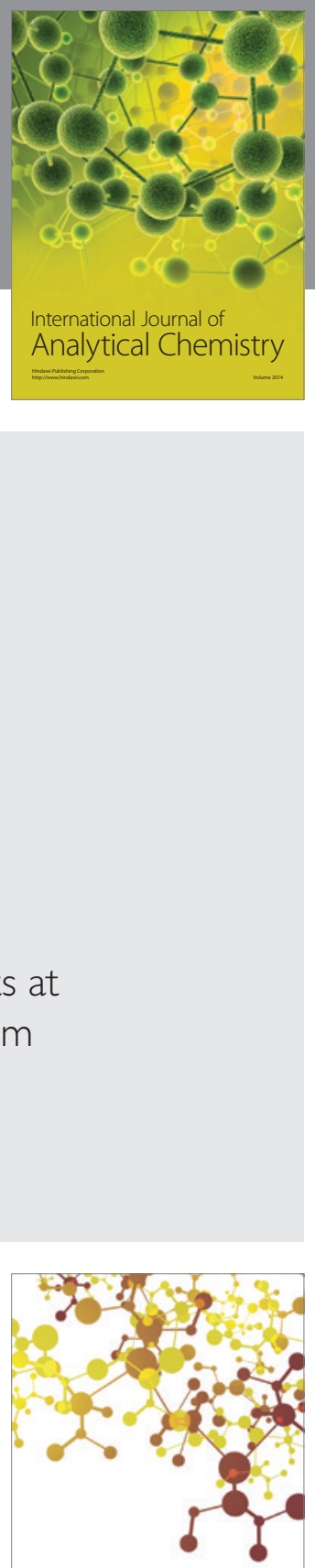

Journal of

Applied Chemistry
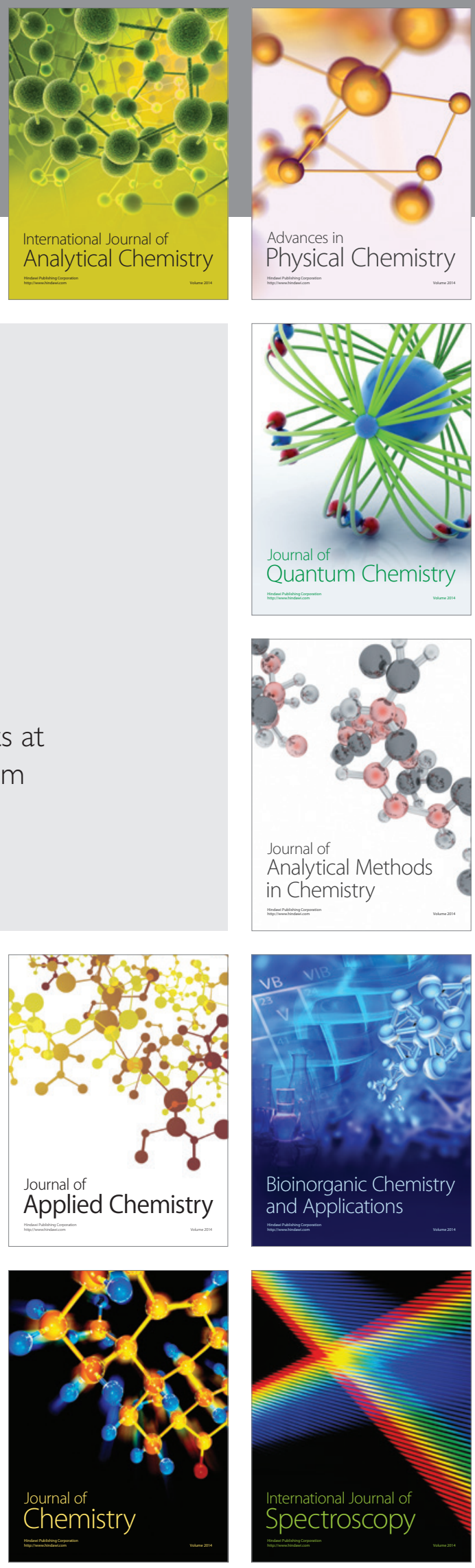